\title{
Evaluasi Program Prevention of Mother to Child HIVTransmission [PMTCT] di RSAB Harapan Kita Jakarta
}

\author{
Martani Widjajanti \\ Kelompok Kerja Alergi Imunologi SMF Anak RSAB Harapan Kita Jakarta
}

\begin{abstract}
Latar belakang. Penularan infeksi HIV (Human Immunodeficiency Virus) dari seorang ibu HIV (+) pada bayinya dapat terjadi selama kehamilan, persalinan, ataupun menyusui. Hal ini dinamakan penularan HIV dari ibu-ke-bayi atau dikenal dengan istilah Mother To Child HIV Transmission (MTCT). Penularan HIV dari ibu ke bayi tersebut dapat dicegah yang dikenal dengan sebutan PMTCT (Prevention of Mother To Child HIV Transmission)

Tujuan. Melakukan evaluasi terhadap kemungkinan infeksi HIV yang terjadi pada bayi yang mengikuti program PMTCT di RSAB Harapan Kita.

Metode. Penelitian deskriptif dengan menggunakan data retrospektif dari rekam medik RSAB Harapan Kita Jakarta dan Rumah Sakit Kanker Dharmais Jakarta. Subyek penelitian adalah bayi dan ibu HIV (+) yang melahirkan di RSAB Harapan Kita Jakarta pada periode 1 Januari 2007-30 November 2010 dan telah mengikuti program PMTCT.

Hasil. Delapanbelas dari 19 bayi yang dilahirkan ibu HIV positif diikutsertakan dalam penelitian ini. Terdapat $3(16,7 \%)$ bayi yang telah melakukan uji diagnostik HIV secara lengkap. Untuk pemeriksaan PCR-RNA HIV pertama, dijumpai 15 (83,3\%) bayi telah melakukan pemeriksaan dengan hasil negatif. Sedangkan untuk pemeriksaan PCR-RNA HIV kedua, 10 bayi $(58,8 \%)$ telah melakukan pemeriksaan, semua memberikan hasil negatif. Untuk pemeriksaan ELISA HIV dilakukan saat usia bayi 18 bulan, dijumpai 5 bayi (50\%) dari 10 bayi yang seharusnya melakukan ELISA HIV sampai dengan November 2010, juga memberikan hasil negatif (virus HIV tidak terdeteksi).

Kesimpulan. Pada semua bayi yang telah menjalani pemeriksaan ELISA HIV, tidak ada satupun yang terdeteksi virus HIV. Sari Pediatri 2012;14(3):167-72.
\end{abstract}

Kata kunci: PMTCT, PCR RNA HIV, Elisa HIV

Alamat korespondensi:

Dr. Martani Widjajanti, SpA. RS Anak dan Bunda Harapan Kita Jakarta, Jl. Letjen S. Parman Kav. 87, Slipi, Jakarta.

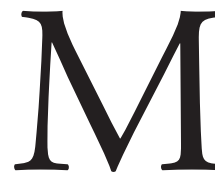

asalah infeksi HIV dan rantai penularannya merupakan salah satu masalah kesehatan masyarakat di Indonesia yang memerlukan perhatian serius dan agaknya akan menjadi penyebab utama penyakit dan kematian di kalangan perempuan dan anak- 
anak. Dalam publikasi rekomendasi WHO maupun UNAIDS tahun 2010 bahwa terdapat 33,4 juta orang dengan HIV/AIDS di seluruh dunia, di antaranya 15,7 juta (47\%) perempuan dan 2,1 juta anak-anak berusia kurang dari 15 tahun. $^{3}$ Secara global, HIV merupakan penyebab utama kematian perempuan usia reproduksi. Sepanjang usia reproduksi aktif, perempuan HIV positif secara potensial memiliki risiko untuk menularkan HIV kepada bayi berikutnya jika hamil kembali.

Penularan HIV dari ibu ke bayi merupakan akhir dari rantai penularan yang umumnya didapat dari seorang laki-laki HIV positif. Jumlah masyarakat yang hidup dengan HIV positif di dunia telah meningkat dari sekitar 8 juta jiwa pada tahun 1990 sampai dengan 33 juta pada tahun 2010, dan angka ini masih terus bertambah. ${ }^{1}$ Selama tahun 2008 terdapat 1,4 juta perempuan dengan HIV positif melahirkan di negara berkembang dan terjadi 430,000 bayi terinfeksi HIV, 90\% di antaranya berasal dari penularan ibu ke bayi (mother-to-child transmission/MTCT). Tanpa pengobatan, sekitar setengah dari jumlah anak yang terinfeksi akan meninggal sebelum usia 2 tahun. ${ }^{2}$ Tanpa intervensi, risiko MTCT berkisar antara 20\%-45\% sedangkan dengan intervensi spesifik risiko MTCT dapat berkurang hingga $2 \%$ pada populasi ibu yang tidak menyusui dan hingga $5 \%$ pada populasi ibu menyusui. $^{3}$

Di Indonesia, hingga akhir tahun 2009, jumlah masyarakat dengan HIV dilaporkan sekitar 24,000 kasus. Penularan HIV dari ibu ke bayi dapat dicegah dengan program PMTCT. Di negara maju, risiko seorang bayi tertular HIV dari ibunya sekitar < $2 \%$, hal ini karena tersedianya layanan optimal untuk pencegahan penularan HIV dari ibu ke bayi. Tetapi di negara berkembang atau negara miskin dengan akses intervensi minimal, risiko penularan meningkat menjadi antara 25\%-45\%. Masyarakat sering beranggapan bahwa bayi yang dilahirkan oleh ibu HIV positif pasti akan terinfeksi virus HIV. Pada kenyataannya, 60\%-75\% anak tersebut tidak terinfeksi walaupun tidak ada intervensi apapun. Penyebaran MTCT HIV dapat terjadi 5\% pada saat dalam kandungan, 15\% pada saat persalinan, dan 10\% melalui pemberian ASI. ${ }^{4,5}$ Strategi preventif selama kehamilan terbukti mengurangi risiko MTCT pada HIV sebesar 1\%-2\%, yang meliputi ARV profilaksis selama kehamilan dan melahirkan hingga bayi berusia 6 minggu setelah lahir, pertolongan persalinan dengan cara bedah kaisar elektif sesudah usia kehamilan matang, dan pencegahan pemberian ASI. ${ }^{6}$ Pencegahan penularan HIV dari ibu ke bayi dilaksanakan secara komprehensif dengan menggunakan empat prong yaitu, $3,7-9$

Prong 1 : Pencegahan penularan HIV pada perempuan usia reproduksi;

Prong 2 : Pencegahan kehamilan yang tidak direncanakan pada perempuan HIV positif;

Prong 3 : Pencegahan penularan HIV dari ibu hamil HIV positif ke bayi yang dikandungnya;

Prong 4 : Pemberian dukungan psikologis, sosial dan perawatan kepada ibu HIV positif beserta bayi dan keluarganya.

Untuk menentukan bayi tidak mengidap HIV, diperlukan minimal dua kali pemeriksaan PCR RNA HIV dengan hasil negatif, yaitu pada usia 4-6 minggu dan pada usia 4-6 bulan. Pada saat bayi berusia 18 bulan dilakukan pemeriksaan zat anti terhadap HIV dengan cara ELISA untuk konfirmasi. ${ }^{4}$

Pengalaman dan keberhasilan pelaksanaan pencegahan penularan HIV dari ibu ke bayi di berbagai negara di dunia telah dinyatakan dalam rekomendasi WHO yang diperbaiki terus dan diadaptasi ke dalam Pedoman Nasional PMTCT, sekaligus merevisi pedoman yang telah ada sebelumnya.

\section{Program PMTCT di RSAB Harapan Kita}

Pelaksanaan program pencegahan penularan HIV dari ibu ke bayi atau PMTCT HIV di RSAB Harapan Kita telah mulai dilakukan secara bertahap sejak bulan Januari 2007, kemudian dilaksanakan secara terpadu (berdasarkan Pedoman Nasional PMTCT 2008) oleh Tim Layanan HIV/AIDS RSAB Harapan Kita, sesuai dengan SK Direktur Utama RSAB tertanggal 11 September 2008, yang antara lain terdiri dari dokter spesialis anak, dokter spesialis obstetri dan ginekologi, ahli psikologi, tenaga perawat, tenaga pencatatanpelaporan dan tenaga farmasi. Menurut Havens $\mathrm{dkk}^{5}$ Dokter spesialis anak memegang peran kunci pada PMTCT dengan cara melakukan deteksi dini infeksi HIV pada bayi. Walaupun infeksi HIV pada ibu tidak diketahui sebelum proses kelahiran, profilaksis ARV pada bayi baru lahir dari ibu HIV positif harus diberikan untuk mengurangi risiko MTCT HIV, dan mengurangi risiko transmisi infeksi HIV dengan menyarankan tidak memberikan ASI. ${ }^{5}$ 
World Health Organization (WHO) mempunyai panduan untuk pemberian obat anti retro viral (ARV) pada ibu hamil, yaitu pemberian ARV untuk semua wanita dengan $\mathrm{CD} 4 \leq 350 \mathrm{sel} / \mathrm{mm}$. Pada wanita yang tidak memerlukan ARV, dapat diberikan ARV profilaksis pada awal trimester ke-2 dan sebagai profilaksis postpartum. Bila ibu dalam keadaan tertentu terpaksa harus memberikan ASI, diberikan ARV profilaksis pada ibu dan bayi selama masa menyusui. ${ }^{9}$

Program PMTCT di RSAB Harapan Kita dijalankan dengan mengikuti Pedoman Nasional PMTCT, meliputi antara lain pemberian ARV pada ibu hamil dan pada bayi setelah lahir. Semua ibu hamil dengan HIV positif yang memenuhi kriteria untuk mendapatkan ARV harus mulai mendapat ARV, sedangkan ibu hamil dengan HIV positif yang tidak memerlukan ARV harus diberikan profilaksis ARV untuk mencegah penularan ibu ke bayi. Proses persalinan sebaiknya dengan cara bedah kaisar yang terencana ${ }^{3}$. Setelah bayi lahir, bayi dikeringkan dan ditangani dengan standar pencegahan universal. Bayi tidak diberi ASI, namun diberikan susu formula pengganti ASI sesuai dengan kriteria AFASS (acceptable $=$ mudah diterima, feasible $=$ mudah dilakukan, affordable = harga terjangkau, sustainable = berkelanjutan, safe = aman penggunaannya) dari WHO. ${ }^{2,3,7}$ Dua belas jam setelah lahir, maksimal dalam 72 jam setelah lahir, bayi mendapatkan ARV profilaksis yang terdiri dari ${ }^{6,10,11}$ Zidovudine $2 \mathrm{mg} / \mathrm{kg}$ BB/ kali setiap 6 jam selama 6 minggu untuk bayi cukup bulan. Bayi dengan gestasi kurang dari 34 minggu mendapat $1,5 \mathrm{mg} / \mathrm{kg} \mathrm{BB} /$ dosis, diberikan 2 kali per hari selama 2 minggu pertama, diikuti dosis yang sama 3 kali perhari selama 2 minggu berikutnya, dan dosis $2 \mathrm{mg} / \mathrm{kg} \mathrm{BB} /$ hari diberikan 4 kali per hari selama 2 minggu terakhir. Nevirapine dosis tunggal $2 \mathrm{mg} / \mathrm{kg}$ BB diberikan saat usia bayi 48-72 jam. Pada bayi dilakukan pemantauan efek samping obat, pertumbuhan berat badan dan perkembangan, serta diberikan imunisasi sesuai dengan jadwal yang berlaku. Untuk menentukan bayi tidak mengidap HIV, diperlukan minimal dua kali pemeriksaan dengan hasil negatif. Pada usia 4 minggu, dilakukan pemeriksaan PCR RNA HIV jika hasil negatif ARV dihentikan. Mulai usia 4 minggu diberikan profilaksis kotrimoksazol untuk mencegah infeksi oportunistik Pneumocystis Carinii Jiroveci (PCP), diberikan sampai dinyatakan HIV negatif pada pemeriksaan PCR RNA HIV kedua, yaitu pada usia 4-6 bulan. Jika hasil negatif kotrimoksasol profilaksis dihentikan. Pada usia 18 bulan dilakukan pemeriksaan antibodi terhadap HIV (ELISA) untuk konfirmasi. ${ }^{10}$

Tujuan dari penelitian untuk melakukan evaluasi terhadap kejadian infeksi HIV pada bayi yang lahir di RSAB Harapan Kita Jakarta dari ibu HIV (+) yang mengikuti program PMTCT di RS Kanker Dharmais dan RSAB Harapan Kita. Evaluasi dibuat berdasarkan pemeriksaan PCR-RNA HIV yang pertama saat bayi usia 4-6 minggu, pemeriksaan PCR-RNA HIV yang kedua saat bayi berusia 4-6 bulan dan yang ketiga berdasarkan pemeriksaan ELISA HIV saat bayi berusia 18 bulan.

\section{Metode}

Penelitian deskriptif dilakukan dengan menggunakan data dari rekam medik RSAB Harapan Kita Jakarta dan rekam medik RS Kanker Dharmais Jakarta. Hasil pemeriksaan laboratorium juga didapat dengan cara menghubungi orang tua pasien, apabila data tidak dijumpai dalam rekam medik pasien. Subyek penelitian adalah bayi yang mengikuti protokol Program PMTCT yang berlaku di RSAB Harapan Kita Jakarta, dilahirkan dari ibu yang telah dinyatakan terinfeksi HIV sebelum atau selama kehamilan, dan mengikuti Program PMTCT untuk ibu hamil sesuai protokol yang berlaku di RS Kanker Dharmais Jakarta. Ibu tersebut melahirkan di RSAB Harapan Kita Jakarta, pada periode 1 Januari 2007-30 November 2010.

\section{Hasil}

Dalam kurun waktu 1 Januari 2007-November 2010, tercatat 19 orang ibu HIV positif yang melahirkan di RSAB Harapan Kita dengan usia $\leq 20,21-30,31-35$, dan $>35$ tahun berturut-turut $1(5,3 \%), 13(68,4 \%), 4$ (21\%), dan $1(5,3 \%)$ kasus. Di antara 19 ibu tersebut 6 orang ibu (31,6\%) adalah kehamilan pertama, 8 (42\%) kehamilan kedua, $3(15,8 \%)$ kehamilan ketiga, dan $2(10,6 \%)$ kehamilan keempat. Diagnosis HIV pada ibu tersebut, telah ditegakkan sejak tahun 2001-2008. Distribusi usia ibu tertera pada Tabel 1.

Untuk pemeriksaan CD4 dan viral load selama kehamilan, $15(79 \%)$ orang ibu telah melakukan pemeriksaan CD4 dan 4 (21\%) orang ibu telah melakukan pemeriksaan viral load. Kelompok lain 
data tidak didapatkan. Kelimabelas ibu melakukan pemeriksaan CD4 pada saat usia kehamilan yang berbeda di antara 1-8 bulan. Empat orang ibu melakukan pemeriksaan viral load antara usia kehamilan 3-9 bulan. Pemberian profilaksis ARV selama kehamilan dilakukan pada $14(73,7 \%)$ orang ibu (Tabel 1$)$.

Kesembilan belas ibu telah menjalankan prosedur persalinan melalui bedah kaisar secara elektif dan tidak memberikan ASI kepada bayinya sejak awal kelahiran. Untuk profilaksis terhadap bayi, semua bayi mendapatkan profilaksis berupa zidovudine dan nevirapine, $2(10,5 \%)$ bayi lahir pada usia kurang dari 34 minggu.

Semua bayi mendapatkan dosis tunggal $2 \mathrm{mg} / \mathrm{kg}$ $\mathrm{BB}$, baik untuk bayi kurang bulan maupun cukup bulan. Tiga $(15,8 \%)$ bayi mendapatkan profilaksis zidovudine $4 \mathrm{mg} / \mathrm{kg} \mathrm{BB} / \mathrm{kali}$, dan diberikan tiap 12 jam, sedangkan $1(5,2 \%)$ bayi mendapatkan $2 \mathrm{mg} /$ $\mathrm{kg} \mathrm{BB} / \mathrm{kali}$ yang diberikan tiap $12 \mathrm{jam}$. Dua bayi

Tabel 1. Karakteristik klinis dan laboratorium ibu HIV (+)

\begin{tabular}{lc}
\hline Usia (tahun), $(\mathrm{n}=19)$ & Kasus \\
\hline$\leq 20$ & 1 \\
$21-<30$ & 13 \\
$31<35$ & 4 \\
$>35$ & 1 \\
Kehamilan (n=19) & 6 \\
Pertama & 8 \\
Kedua & 3 \\
Ketiga & 2 \\
Keempat & \\
Kadar CD4 (n=15) & 4 \\
CD4<200 & 9 \\
CD4 200-400 & 2 \\
CD4 >400 & \\
Pemberian profilaksis ARV (n=19) & 4 \\
Kombinasi staviral 2x1, hiviral 2x1, aluvia 2x2 & 4 \\
Kombinasi staviral 2x1, hiviral 2x1, neviral 2x1 & 4 \\
Kombinasi duviral 2x1, aluvia 2x2 & 5 \\
Kombinasi duviral 2x1, neviral 2x1 & 1 \\
Tidak ada data & 5 \\
\hline
\end{tabular}

(10,5\%) yang lahir kurang bulan mendapatkan profilaksis zidovudine $1,5 \mathrm{mg} / \mathrm{kg} \mathrm{BB} / \mathrm{kali}$ diberikan tiap 12 jam selama 2 minggu pertama, kemudian 2 $\mathrm{mg} / \mathrm{kg} \mathrm{BB} / \mathrm{kali}$ diberikan tiap 8 jam selama 2 minggu kedua, dan $2 \mathrm{mg} / \mathrm{kg}$ BB/kali diberikan tiap 6 jam selama 2 minggu ketiga. Di antara 19 bayi yang lahir dari ibu HIV (+), satu orang bayi $(5,2 \%)$ meninggal dunia pada umur 3 hari dengan diagnosis hipertensi pulmonal persisten.

Jadi 18 orang bayi mengikuti program PMTCT RSAB Harapan Kita pada periode penelitian. Dari 18 orang bayi tersebut, hanya 3 orang bayi menjalani pemeriksaan uji diagnostik HIV secara lengkap, yakni pemeriksaan PCR-RNA HIV pertama saat bayi usia 4-6 minggu, pemeriksaan PCR-RNA HIV kedua saat bayi berusia 4-6 bulan, dan terakhir pemeriksaan ELISA HIV saat bayi berusia 18 bulan (Tabel 2).

\section{Pembahasan}

Infeksi HIV dari seorang ibu dengan positif HIV kepada bayi dapat terjadi selama proses kehamilan, melahirkan, persalinan, atau menyusui (MTCT). Dilaporkan 25\%-35\% transmisi dari ibu ke bayi terjadi selama proses kehamilan, dan $70 \%-75 \%$ terjadi saat proses melahirkan/ persalinan. ${ }^{10}$ Oleh karena itu, penting upaya intervensi untuk mengurangi jumlah anak yang tertular yang disebut pencegahan penularan HIV dari ibu ke bayi atau lebih dikenal dengan PMTCT. Program PMTCT di RSAB Harapan Kita meliputi pencegahan penularan dari ibu ke bayi berupa pemberian ARV dan persalinan dengan bedah kaisar, ${ }^{2,3}$ pertolongan setelah persalinan dengan pemberian ARV profilaksis pada bayi yang digunakan saat ini yang terdiri dari zidovudine dan nevirapine. ${ }^{6,10,11}$ Selain itu dilakukan pemantauan monitor efek samping obat, pertumbuhan berat badan, serta diberikan imunisasi. ${ }^{10}$ Untuk menentukan bayi tidak mengidap HIV, diperlukan minimal dua kali pemeriksaan PCR RNA HIV pertama pada usia 4 minggu dan pemeriksaan yang kedua pada usia 4-6

Tabel 2. Uji diagnostik HIV pada bayi PMTCT

\begin{tabular}{lccc}
\hline Jumlah & PCR-1 & PCR-2 & ELISA \\
\hline Bayi yang seharusnya melakukan pemeriksaan & 18 & 17 & 10 \\
Bayi yang melakukan pemeriksaan & 15 & 10 & 5 \\
Hasil negatif & 15 & 10 & 5 \\
\hline
\end{tabular}


bulan dengan hasil negative.4. Jika hasil pemeriksaan pertama negatif, ARV tidak dilanjutkan, dan mulai usia 4 minggu diberikan profilaksis kotrimoksazol sampai dinyatakan HIV negatif pada pemeriksaan PCR RNA HIV kedua, yaitu pada usia 4-6 bulan. Kemudian pada saat usia 18 bulan dilakukan pemeriksaan antibodi terhadap HIV (ELISA) untuk konfirmasi. ${ }^{10}$ Dalam kurun waktu penelitian ini, sejak Januari 2007- November 2010, didapatkan total 19 bayi yang lahir dari ibu HIV (+). Satu bayi $(5,2 \%)$ yang meninggal dunia pada hari ke-3 setelah dilahirkan. Bayi tersebut meninggal dengan diagnosis hipertensi pulmoner persisten pada bayi baru lahir. Jadi, total yang mengikuti program PMTCT RSAB Harapan Kita adalah 18 bayi. Dari ke- 18 bayi tersebut, hanya 3 bayi $(16,7 \%)$ yang melakukan uji diagnostik HIV secara lengkap, yakni pemeriksaan PCR-RNA HIV pertama saat bayi usia 4-6 minggu, pemeriksaan PCR-RNA HIV kedua saat bayi berusia 4-6 bulan, dan terakhir pemeriksaan ELISA HIV saat bayi berusia 18 bulan.

Untuk pemeriksaan PCR-RNA HIV yang pertama, 15 bayi telah melakukan pemeriksaan tersebut di RSAB Harapan Kita. Kelimabelas bayi yang sudah melakukan pemeriksaan PCR-RNA HIV pertama tersebut memberikan hasil yang negatif berarti tidak terdeteksi virus HIV dalam darahnya. Untuk pemeriksaan PCR-RNA HIV kedua, 17 bayi hanya 10 bayi melakukan pemeriksaan PCR-RNA HIV kedua dengan hasil negatif. Sedangkan untuk pemeriksaan ELISA HIV yang seharusnya dilakukan saat bayi berusia 18 bulan, hanya ada 5 bayi yang melakukan pemeriksaan dari 10 bayi yang seharusnya sudah melakukan ELISA HIV dan memberikan hasil negatif.

Dalam kepustakaan dikatakan bahwa bayi tidak terinfeksi HIV apabila minimal dua kali pemeriksaan laboratorium tidak ditemukan virus HIV dalam darah. ${ }^{4}$ Dalam kurun waktu penelitian kami, lima orang bayi terbukti tidak terinfeksi HIV dalam darahnya dengan melakukan tiga kali pemeriksaan yang sesuai protokol. Sepuluh orang bayi telah menjalani dua kali pemeriksaan PCR HIV dan tidak ditemukan virus HIV dalam darahnya maka 5 bayi sisanya tidak menjalani pemeriksaan Elisa HIV namun telah menjalani pemeriksaan PCR RNA dua kali dengan hasil negatif sehingga dapat dinyatakan tidak terinfeksi HIV dari ibunya.

Dapat disimpulkan selama kurun waktu penelitian 10 di antara 18 bayi yang diteliti, tidak dijumpai penularan infeksi HIV. Kami masih menunggu 8 orang bayi yang usianya belum mencapai 18 bulan pada saat penelitian dilaporkan maka masih menunggu pemeriksaan ELISA HIV pada usia 18 bulan untuk konfirmasi. Seluruh bayi yang lahir dari ibu HIV (+) dan mengikuti program PMTCT di RSAB Harapan Kita, sebagian bayi tidak menjalani prosedur pemeriksaan laboratorium secara lengkap untuk mendeteksi infeksi HIV pada waktu yang ditetapkan sesuai dengan protokol yang dianjurkan. Walaupun demikian seluruh bayi yang telah melakukan pemeriksaan untuk deteksi virus HIV, memberikan hasil negatif, berarti tidak ditemukan infeksi virus HIV dalam darahnya.

\section{Daftar pustaka}

1. UNAIDS. UNAIDS report on the global AIDS epidemic. 2010. Diakses tanggal 1April 2011. Diunduh dari URL: http://www.avert.org/worldstats. htm

2. Economic Commission for Africa. Preventing mother-tochild transmission of HIV in Africa: issue and challenges. Commission on HIV/AIDS and Governance in Africa, Addis Ababa; 2004.

3. Kementrian Kesehatan Republik Indonesia. Modul pelatihan: Pencegahan penularan HIV dari ibu ke bayi. Departemen Kesehatan RI, Jakarta; 2008.

4. Read JS . Diagnosis of HIV-1 infection in children younger than 18 months in the United States. Pediatrics. 2007; 120:1547-62.

5. Havens PL, Mofenson LM. Evaluation and management of the infant exposed to HIV-1 in the United States. Pediatrics. 2009;123:175-87.

6. Kilewo C, Karlsson K, Massawe A, Lyamuya E, Swai A, Mhalu F, dkk. Prevention of mother-to-child transmission of HIV-1 through breast-feeding by treating infants prophylactically with lamivudine in Tanzania. J Acquir Immune Defic Syndr. 2008;48:31523.

7. Yayasan spiritia. Pencegahan penularan dari ibu-ke-bayi (PMTCT). Yayasan spiritia, Jakarta; 2008. Diakses tanggal 3April 2011 Diunduh dari URL: http://spiritia. or.id/cst/bacacst.php

8. De Cock KM, Fowler MG, Mercier E, de Vincenzi I, Saba J, Hoff E, dkk. Prevention of mother-tochild HIV transmission in resource-poor countries translating research into policy and practice. JAMA 
2000;283:1175-81.

9. WHO. PMTCT strategic vision 2010-2015: preventing mother-to-child transmission of HIV to reach the UNGASS and millennium development goals: moving towards the elimination of pediatric HIV. December 2009. WHO, Geneva; 2010.
10. Kaizad D, Parikshit T. Prevention of mother to child transmission of HIV infection. J Obstet Gynecol India. 2006;56:390-5.

11. King SM. Evaluation and treatment of the human immunodeficiency virus-1-exposed infant. Pediatrics. 2004; 114:497-505. 